\title{
PHILOSOPHICAL BACKGROUND OF THE COSMOLOGICAL POLEMICS IN CONTRA MANICHAEOS BY JOHN OF DAMASCUS
}

\author{
VLADIMIR BARANOV \\ Novosibirsk State University of Architecture, Design and Arts \\ baranovv@academ.org
}

\begin{abstract}
This article analyzes the philosophical arguments used by John of Damascus against the Manichaean dualist cosmological system in his Dialogue contra Manichaeos, showing some parallels with his Dialectica, and revealing a common Aristotelian background. The philosophical argument in the Dialogue seems to be a practical application of philosophical doctrines formulated in the Dialectica. From a wider perspective of antiManichean polemics used in part for instructional purposes for students of philosophy and theology in Late Antiquity, the conclusion is made that the purpose of the Dialogue was aimed not so much against the Manichaean cosmogony and cosmology, but against the Manichaean theodicy which might have been attractive to some Christians of John's times.
\end{abstract}

KEYWORDS: John of Damascus, Manichaeism, Aristotle, syllogistic proof, substance, contraries, Neoplatonic education.

* This study was supported by the Russian Foundation for Basic Research, Project No. 20011-41004 "Treatise of John Philoponus 'On the Creation of the World' in the context of the Middle Eastern Syrian-Palestinian and Byzantine Theological (Christological, anthropological, cosmological) Traditions".

At the time of social and political changes in Syria and Palestine in the eighth century, ${ }^{1}$ a clear and simple solution to the problem of evil, offered by Manichaean dualism ${ }^{2}$ must have appealed to many Muslims and Christians, ${ }^{3}$ thus triggering

${ }^{1}$ Tannous 2010. On the situation in the Holy Land at the turn of the eighth century, see Griffith 2006, Griffith 2011, Griffith, 2016, Schadler 2018.

${ }^{2}$ On the presence of the Manichees in Syria and Palestine at the time of John of Damascus, see Ables 2019; Reeves 2011, 152-154.

¿XOАH Vol. 15. 2 (2O21)

(C) Vladimir Baranov, 2021

schole.ru; classics.nsu.ru

DOI:10.25205/1995-4328-2021-15-2-573-594 
the appearance of both Muslim and Christian anti-Manichaean polemics. ${ }^{4}$ The problem of evil was resolved in Manichaeism by relegating all good attributes to one divine, beneficial principle of light, and all bad attributes to the other evil, dark, and malevolent principle of matter. In its scope, the Dialogue contra Manichaeos of John of Damascus consists of two parts. In the first part John of Damascus refutes the Manichaean cosmologic myth on the basis of Aristotelian syllogisms. Then the "Manichean" interlocutor almost disappears from the scene and the second part of the Dialogue discusses the problems associated with the presence of evil in the world which was created by a benevolent God, His foreknowledge, and divine providence, masterfully rethinking the solutions offered in the Homily That God Is Not the Author of Evil by Basil of Caesarea. ${ }^{5}$ This article will examine more closely the first part of the Dialogue and consider several counterarguments of John of Damascus against some provisions of the Manichaean dualist system.

In the beginning of the Dialogue, John of Damascus presents the Manichaean cosmogonic myth: there were two primordial principles, good and evil, each one in its own place, "and the good one is called the Good Tree, containing and producing every good, incapable of bringing evil fruit, and the evil one - darkness, decay, the Evil Tree, containing all bad and evil things, incapable of bringing good fruit..." ${ }^{6}$ This evil or matter was lifeless, motionless, ugly and dark, and then it rebelled against itself, and its fruits fought with each other. When some of them fled and others pursued, they reached the boundaries of the realm of light. Seeing the light, they desired its beauty, stopped fighting with each other, made a mutual agreement, and attacked the light. And the Good One sent power from himself, and in the battle, the Good One allowed a particle of light to be taken away from him and devoured by the rulers of darkness in order to overcome evil by means of the particle that he gave away. This resulted in a mixture of good and evil in the

\footnotetext{
${ }^{3}$ S. Stroumsa and G. Stroumsa suggested that Manichaean dualism might have fostered the discussions on free will in early Islam and ultimately resulted in shaping some basic Muslim doctrines of theodicy (Stroumsa, Stroumsa 1988, 52-54); see also Reeves 2011; Baran Tekin 2017, 1-9; Griffith 2011, and Griffith 1987, 94-96, 99-102.

${ }^{4}$ On the polemics against Manichaeism in John of Damascus, see Louth 2002, 61-71. On the cultural and theological environment of John of Damascus, see Awad 2018.

${ }^{5} P G$ 31, 344B-345A. Although the editor of the Dialogue B. Kotter says in the introduction to the text that no detectable earlier source texts can be identified (Kotter 1981, 344), a number of textual and conceptual parallels make it possible to identify Basil's Homily as a primary source for John of Damascus theodicy and doctrine of divine foreknowledge in the Dialogue (Baranov 2019).

${ }^{6}$ ed. Kotter 1981, 352.2-6.
} 
world: souls emerged from the particle of goodness, and bodies emerged from the

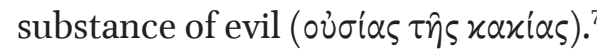

This basic myth appears in many variations; ${ }^{8}$ in terms of verbal formulations, the closest version to the one presented by John of Damascus can be found in Theodoret of Cyrus' Haereticarum fabularum compendium, including the metaphorical description of the primordial good principle as a good tree, with good fruit, and matter as a bad tree bearing bad fruit, as well as the mixed current state of the world. ${ }^{9}$ Manichaeism originated in the Persian-Babylonian Judeo-Christian environment with its specific metaphorical and poetic frame of mind, ${ }^{10}$ and did not attempt to formulate its cosmogony and cosmology in structurally arranged ontological terms associated with causality, as was the case with the Greek philosophical tradition. The evil in this system was not a strictly moral or ontological category but should rather be viewed as a personification and antithesis of anything morally or esthetically good and beautiful."

Triggered by the drama of evil in this world and projecting this perception onto the level of cosmic drama of the particles of light entrapped and imprisoned in matter, the Manichaean dualism never succeeded in articulating this opposition on a strictly rational and philosophical level or in formulating a coherent terminological and conceptual system supporting it. ${ }^{12}$ When Manichean missionaries entered the Greek-speaking world, they were forced to translate their myth and its constituent elements not only into the Greek language but also into the Greek frame of mind, and use such concepts as principles ( $\dot{\alpha} p \chi \alpha i)$, matter ( $\left.\tilde{v}^{\lambda} \eta \eta\right)$, substance $\left(\iota^{\prime} \sigma^{\prime} \alpha\right)$, and nature $(\varphi \dot{v} \sigma \varsigma),{ }^{13}$ all of which had enormously rich philosophical meaning, thus causing perplexity in philosophers and becoming susceptible to criticism on philosophical grounds. A "Christianized" version of the Manichaean myth ${ }^{14}$ is described by Theodore Abū Qurrah, the Bishop of Harran (ca. 750-ca.

\footnotetext{
${ }^{7}$ Ibid., 352-353.

${ }^{8}$ For an overview of the Manichaean doctrine, see Lieu 1986-1987. For a list of Patristic anti-Manichaean works, see Lieu 1985-1986, 464-469. On Manichaeism in the Roman Empire, see Lieu 1992 and Tardieu 2008. On the anti-Manichaean polemics, see Klein 1991; Bennett 2001; Fox, Sheldon, Lieu 2010; Lieu, Sheldon 2011; Smagina 2011; Gardner, Lieu 2004; Khosroev 2007, 122-165, and Esmailpour 2005.

${ }^{9} P G 83,377 \mathrm{BD}$. On the image of good and bad trees in Manichaeism, see Coyle 2ooga. On Theodoret's version of the Manichean myth, see Bennett 2009 .

${ }^{10}$ On the cultural and religious background of Mani, see Khosroev 2007, 109-122.

"On the notion of "good" in Manichaeism, see Coyle 2oogb.

${ }^{12}$ Puech 1979, 118.

${ }^{13}$ Pedersen 1989, 46-50.

${ }^{14}$ On the Christian influences on the Manichaean doctrine, see Bermejo 2015.
} 
825), who started his ecclesiastical career just a generation after John of Damascus, and described his encounter with the Manichees. These Manichees claimed to be true Christians possessing the true Gospel; they described their primordial principles as substances, and associated the evil principle with Satan.

The true Gospel is in our possession: it is the one which the twelve apostles have written. There is no Church except for the one which we have, and no one is (truly) Christian except for us. No one discerns the (proper) interpretation of the Gospel apart from Mānī, our founder. Thus has he taught us: Before this world was created, there were two gods whose substances were each different. One of them was Light, Goodit is the good deity-and the other was Evil, Darkness; namely, Satan. ${ }^{15}$ In the beginning, each one of them occupied its own territory. Then Darkness noticed the Radiant One and its beauty and its excellence. ${ }^{16}$ Filled with desire for it, it pounced upon it and fought with it, wishing to capture it. The Radiant One strove to combat it, but Darkness was on the verge of gaining victory over it. As the Radiant One was in mortal fear, it lopped off a piece of itself and flung it to it, and Darkness swallowed it. Heaven and earth and everything between them were created from the nature of Darkness and from the nature of the piece that the Radiant One threw to him: they came into being by means of (their) combination. For example, humans are created having an internal soul and an external body. They claim that the soul derives from the nature of the Radiant One and the body derives from the nature of Satan, the Dark One. ${ }^{17}$

${ }^{15}$ The discrepancy between the goodness of the original creation and the observable reality is closely related to the figure of the devil as the main actor and instigator of evildoing. However, in order to remove even the slightest possibility that the devil somehow embodied absolute evil, John of Damascus argued that even the devil was not completely evil since he still participated in being which was a goodness originating from the good God, and possessed free will as a rational creature (Dialogus contra Manichaeos, 32-36, ed. Kotter 1981, 372-373).

${ }^{16}$ This version of the myth notably omits a very important Manichaean notion of "the

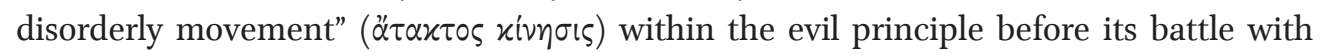
the principle of light. Cf. John of Damascus, Dialogus contra Manichaeos, 61: "There was, as you say, matter without beginning, unoriginate, in its own borders, eternally disorder-

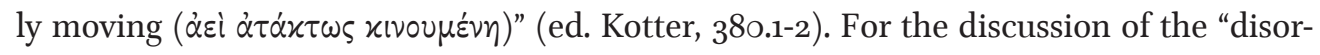
derly movement" in the Conversation of John the Orthodox with a Manichaean and its sources in Titus of Bostra, see Bennett 2009, 38-39; Troje 1948.

${ }^{17}$ Theodore Abū Qurra, On the Existence of the Creator and the True Religion; ed. Dick 1982, 205.14-208.11; cited in Reeves 2011, 152-153. 
After citing the myth, Theodore Abū Qurrah added an important remark concerning the "intuitive" distribution of empirical phenomena in accordance with the two principles among his Manichees:

So too for the condition of all things: whatever in them that is good and pleasant is from the nature of the Radiant One, and whatever is not good and harmful is from the nature of the Dark One. For example, water drowns the one who is submerged in it but invigorates and pleases the one who drinks it. The part (of water) that invigorates is from the Radiant One, while that which drowns and ruins is from Darkness. As for serpents, scorpions, lions, leopards, crawling creatures, and their sort, all these are from Darkness. ${ }^{18}$

Similarly, the Early Neoplatonic philosopher Alexander of Lycopolis who encountered one of the first Manichaean missionaries disguised as students in his school five hundred years before Theodore, thus described his indignation at their methods of reasoning, combining attempts at philosophizing with "poetical fables":

The reason I say this is that I know for a fact that people of this sort [that is, the Manicheans], whenever deficient in proofs, bring together from all sides certain matters derived from poetry to use them as a defence of their private doctrines. However, they would not have done so if they had ever consulted any author you would like to suggest with any amount of care. ${ }^{19}$

Yet, the greatest stumbling stone of the Manichaean cosmology was not even in the existence of the two opposing primordial principles of the universe, but in the mixed state resulting from the attraction of the dark principle to the light and the ensuing cosmic battle, which implied that these principles were not completely alien to each other but had some common grounds. ${ }^{20}$

Before presenting and refuting the Manichaean myth, John of Damascus starts his Dialogue with an argument about the scope of logical reasoning:

Orthodox: Since we came together to make a logical inquiry between ourselves, I will ask you: what is our goal? Manichaean: To compete in inquiring about faith in order to find the truth. O: But what is truth? M.: Establishing and acknowledging that which exists. O.: Is falsehood opposite to truth? M.: In every respect. O.: Why do you say so?

\footnotetext{
${ }^{18}$ Ibid., 153 .

${ }^{19}$ van der Horst, Mansfeld 1974, 71 of ed. Brinkmann 1895, 16.21-17.2. On Alexander of Lycopolis' anti-Manichaean doctrine, see van Oort 2013 (with bibliography).

${ }^{20}$ Coyle 2oogb, 57-58.
} 
M.: Because truth is knowledge of existing beings, and falsehood is [knowledge] of that which is non-existing. O.: You answered incorrectly that truth is the knowledge of existing beings, and falsehood is knowledge of that which is non-existing, since something non-existent cannot be known. M.: What then is falsehood? O.: Ignorance of the existing beings. M.: Right. O.: So, if truth is knowledge of existing beings, and falsehood is ignorance of existing beings, then tell me: is knowledge a possession? M.: Yes. O.: If knowledge is a possession, then ignorance, of course, is privation. M.: Ignorance is also possession. O.: What is ignorance? M.: Not possessing knowledge. O.: Does the particle "not" indicate privation or presence and possession? M.: "Not" shows privation. O.: Do we call non-existing that which is deprived of existence? M.: Sure. O.: So, if ignorance is the lack of knowledge, and "not" indicates privation, ignorance is therefore privation, not possession. M.: Right. O.: Therefore, if truth is knowledge, it is clear that it is possession, and if falsehood is ignorance, according to true reasoning, it is privation. So, it turns out that truth is possession, and falsehood is privation; and truth is an existing thing, while falsehood is a non-existing thing. M.: Certainly. O.: Is evil true or false? M.: False. O.: So, evil is non-existent, but is privation of being and non-existent, and opposite to goodness as privation of possession. ${ }^{21}$

At first sight this seems to be a "sophist" argument about words, aimed at getting an upper hand in the conversation with a gullible Manichaean and demonstrating his philosophical incapacity. In fact, this is an introduction to the main point of polemics against the Manichaean concept of two independent ontological principles: denial of substantial status to the evil principle and considering it as an accident in the substance of all existing beings. Moreover, the Dialectica makes it clear that philosophy for John of Damascus was not the "handmaid of theology": by combining school definitions of philosophy as knowledge of beings, imitation of God, and moral doctrine, he defined it as the fundamental path to true knowledge of God since philosophy as "the love of wisdom" is the love of God. ${ }^{22}$ His anti-Manichaean arguments can be best seen if we consider parallel-

\footnotetext{
${ }^{21}$ Dialogus contra Manichaeos, 1, ed. Kotter 1981, 351.1-26. Translations of the Dialogue are mine.

${ }^{22}$ “... philosophy is knowledge of both divine and human things, that is to say, of things both visible and invisible... Still again, philosophy is the making of one's self like God. Now, we become like God in wisdom, which is to say, in the true knowledge of good; and in justice, which is a fairness in judgment without respect to persons; and in holiness, which is to say, in goodness, which is superior to justice, being that by which we do good to them that wrong us. Philosophy is the art of arts and the science of sciences. This is because philosophy is the principle of every art, since through it every art and science has been invented. Now, according to some, art is what errs in some people and science what errs in no one, whereas philosophy alone does not err. According to others, art is
} 
ism between the philosophical arguments in the Dialogue as practical applications of the conceptual framework presented in the Dialectica. ${ }^{23}$

The Dialectica has survived in a short version of fifty chapters and extensive revision (67 or 68 chapters), both belonging to John of Damascus and was first mentioned in a polemical treatise of the Miaphysite Patriarch Elias $(706-728) .{ }^{24}$ The first layer of the text containing the concepts adopted from the Eisagoge of Porphury can be dated to the late seventh-early eighth century. Later John of Damascus included several sources going back to the Categories of Aristotle. The Dialectica continues the tradition of Christian textbooks of logic which drew on the commentaries on Aristotle written in Alexandria in the fifth and sixth centuries. Christian collections would replace the names in the examples, such as Socrates and Plato, by names such as Peter and Paul, and focus not on elaborating the thought of Aristotle but on the concepts important for defending the Christian faith using logic-based polemics. ${ }^{25}$ However, even though Byzantine logic was clearly Aristotelian in its foundations, the interpretation of Aristotle was influenced by Neoplatonic exegesis and the Christian patristic tradition of logic. ${ }^{26}$

In the introductory chapters of the Dialectica, John presents his concept of knowledge and its scope in very similar terms as it appears in the introductory dialogue with the Manichaean cited above. According to Damascene, knowledge can only be of things which exist, while falsehood is privation and ignorance:

Nothing is more estimable than knowledge, for knowledge is the light of the rational soul. The opposite, which is ignorance, is darkness. Just as the absence of light is darkness, so is the absence of knowledge a darkness of the reason... By knowledge I mean the true knowledge of things which are, because things which have being are the object of knowledge. False knowledge, in so far as it is a knowledge of that which is not, is ignorance rather than knowledge. For falsehood is nothing else but that which is not. Now, since we do not live with our soul stripped bare, but, on the con-

that which is done with the hands, whereas science is any art that is practiced by the reason, such as grammar, rhetoric, and the like. Philosophy, again, is a love of wisdom. But, true wisdom is God. Therefore, the love of God, this is the true philosophy" (ed. Kotter, 1969, 56.1-27; transl. Chase 1958, 11). These are the standard definitions of philosophy taught to the students of the Neoplatonic philosophical schools of Athens and Alexandria in the fifth and sixth centuries (Ierodiakonou, O'Meara 2008, 712).

${ }^{23}$ On the reworking of the Aristotelian conceptual framework in the Dialectica, see Erismann 2010.

${ }^{24}$ Van Roey 1944.

${ }^{25}$ Roueché 1974; Roueché 1980.

${ }^{26}$ Erismann 2017, 364 . 
trary, have it clothed over, as it were, with the veil of the flesh, our soul has the mind as a sort of eye which sees and has the faculty of knowing and which is capable of receiving knowledge and having understanding of things which are $\langle\ldots\rangle$ Philosophy is knowledge of things which are in so far as they are, that is, a knowledge of the nature of things which have being... ${ }^{27}$

Only things which exist or possess being can be defined, analyzed, known, comprehended, and properly spoken about. In his polemics with the Manichaean doctrine, John of Damascus proposed to make generalizations of empirical reality not according to "horizontal" beneficial or malevolent principles, but according to the vertical hierarchy of individuals, species, and genera, culminating in substance as a universal attribute of everything including God.

All existing things are united by their most general commonness of existence or substance. In the Dialectica, John of Damascus mentioned the distinction between substance as the universal commonness of beings, and nature as the genus referring to the "pagan philosophers," qualifying that the Fathers used "substance" and "nature" in the same sense ${ }^{28}$ However, he actively employed the "pagan" notion of substance as the most universal commonness of all beings in his Dialogue, adopting the anti-Manichaean philosophical argument used already by Titus of Bostra, that substances cannot be contrary to each other, and good and evil are not substances but qualities existing in a substance as the sole principle and commonality of all beings, based on Aristotle's Categories: ${ }^{29}$

O: ...And how do you say that the two principles which you have invented have nothing in common? For if both exist, and one substance is an unoriginate and eternal

${ }^{27}$ Ed. Kotter, 1969, 53.1-17; 56.1-3; transl. Chase, 1958, 7-8, 11. On the treatise, see Richter 2009, 38-53.

${ }^{28}$ "In this same way the pagan philosophers stated the difference between ovं $\sigma^{\prime} \alpha$, or substance, and $\varphi v ं \sigma \iota \varsigma$, or nature, by saying that substance was being in the strict sense, whereas nature was substance which had been made specific by essential differences so as to have, in addition to being in the strict sense, being in such a way, whether rational or irrational, mortal or immortal. In other words, we may say that, according to them, nature is that unchangeable and immutable principle and cause and virtue which has been implanted by the Creator in each species for its activity $<\ldots>$ The holy Fathers paid no attention to the many inane controversies, and that which is common to and affirmed of several things, that is to say, the most specific species, they called substance, and nature, and form - as, for example, angel, man, horse, dog, and the like" (ed. Kotter 1969, 9394, transl. Chase 1958, 55-56).

${ }^{29}$ "It seems most distinctive of substance that what is numerically one and the same is able to receive contraries" (Categories, 5, 4a1o-12, transl. Ackrill, 1963, 11). 
principle, and the other one is the same, then they are not completely devoid of commonness. For they have a commonality according to being and substance, and because [each one] is an unoriginate and eternal principle. ${ }^{30}$

O.: In terms of existence, is being opposite to being or to non-being?

M.: The existing evil is opposite to the existing good.

O: I did not ask if they are opposite in terms of good and evil, but in terms of existence. For things which exist are not completely opposite, since they have commonness with each other by their very being, while non-being is opposite to being. Thus, if evil is completely opposite to good, then evil does not exist. Therefore evil is privation of being and is called evil, and if good is substance, then evil is devoid of substance, otherwise they cannot be completely opposite. ${ }^{31}$

This argument is the syllogistic expression of the definition of substance encompassing all beings including God from the Dialectica, and is based on Aristotle's statements from the Categories that contraries are predicated of a substance $;^{32}$ that contrary is not a substance and that substance has nothing contrary to it. ${ }^{33}$ As a Christian theologian, at this crucial point of his argument on the common existence of God and created beings, John of Damascus is also forced to

\footnotetext{
${ }^{30}$ John of Damascus, Dialogus contra Manichaeos, 11, ed. Kotter 1981, 357.5-13.

${ }^{31}$ Dialogus contra Manichaeos, 13, ed. Kotter 1981, 357.6-358.13. Cf. Titus of Bostra, Con-
} tra Manichaeos, I, 13, eds. Roman et al. 2013, 29-35; Pedersen 2004, 262-275. Cf. pseudoDidymus, Syllogisms against the Manichees, I. 1.: "No absolute opposition exists between contraries, since the contraries have certain common attributes. White, for example, which is contrary to black, is opposed to the latter in respect of differentiae alone, while colour and quality are common to them. But nothing of this sort [i.e. like white and black] has its opposition in this respect at a prior [i.e. more general] level; for they are all logically posterior to the common attributes and among the common attributes there is no opposition. There must be colour and quality in common if white and black are to exist; in the same way, virtue and vice are logically posterior to quality and disposition. Thus, if there are two unoriginate first principles [i.e good and evil] and these are contraries, then either their opposition is absolute or they have some common attributes. Nothing, however, is regarded as a contrary in an absolute sense; therefore they have common features, such as existence and being substances and whatever else is found to be common to them. The fact that one is good while the other is evil and that one is light while the other is darkness makes them contraries. The fact that they are substances is conceived of as prior to their being good and evil. Their opposition therefore lies not in what they have in common, but rather in what is peculiar to each" (Bennett 1997, 284/302 Greek/translation).

${ }^{32}$ Categories 5, 4a10-22.

${ }^{33}$ Categories 5, 3b24-27. Cf. John of Damascus, Dialectica, 48; ed. Kotter 1969, 113.20-22. 
make a reservation that although God is substance, He exists in a special "suprasubstantial manner:

Being is the common name for all things which are. It is divided into substance and accident. Substance is the principal of these two, because it has existence in itself and not in another. Accident, on the other hand, is that which cannot exist in itself but is found in the substance. For the substance is a subject, just as matter is of the things made out of it, whereas an accident is that which is found in the substance as in a subject... Substance is defined as follows: Substance is a thing which exists in itself and has no need of another for its existence. Accident, however, is that which cannot exist in itself, but has its existence in another. God, then, is substance, and so is every created thing. God, however, even though $\mathrm{He}$ is substance, is super-substantial. ${ }^{34}$

In addition to substance as a universal commonness of beings, John of Damascus turns to the notion of principle ( $\left.\dot{\alpha} \rho \chi^{\prime}\right)$ treating it in the traditional Aristotelian meaning of causality, as opposed to the secondary meaning of causality among the Manichees, who primarily understood $\alpha \rho \chi \eta \dot{~ a s ~ a ~ " n o t i o n a l ~ c o m p a r t m e n t " ~ f o r ~}$ arranging empirical good or bad phenomena. Aristotle stated that $\alpha p \chi \alpha i$ should be understood as causes, and they all are united by the starting-point, whether internal or external, of being, becoming, or knowledge. In the two consecutive chapters in his discussion of the single $\alpha \dot{p} \times \dot{\eta}$ as opposed to the Manichaean multiple $\alpha \rho x \alpha i$, John of Damascus applied what seems to be a variant of the third man argument, disrupting the endless chain of givers of being only by the beginningless first giver, and using inductive reasoning:

M.: Why is God unoriginate?

O.: Because that which is non-existent, does not have being from itself. And how that which has no being from itself, will exist from itself? By necessity that non-being has to receive being from something existing, and the first sharer of being, who has being from himself, will always be unoriginate. ${ }^{35}$

M.: Why is there one beginning and not two?

O.: Because dyad proceeds from monad as the offspring of the monad, and monad is the beginning of dyad, and monad is clearly prior to dyad, and since every thing has one beginning, and if each of beings has one beginning, all things will have one be-

\footnotetext{
${ }^{34}$ Ed. Kotter 1969, 57.1-58.18, 59.61-69; transl. Chase 1958, 13-14.

${ }^{35} \mathrm{Cf}$. Plato, Parmenides 132a-b. In the Hexaemeron I, 6, Basil of Caesarea applies the same kind of argument to prove that "in the beginning" of the creation account was outside of time (ed. Giet 1950, 110-112, 16CD).
} 
ginning, for the judgment applicable to each of beings will apply to all. ${ }^{36}$

In his further refutation of the doctrine of two primordial principles, John dwells on the classification of sources of beginning ( $\dot{\alpha} p \chi \alpha i)$ or causes proposed by Aristotle in the Metaphysics, who formulated various meanings of $\alpha p x \dot{\eta}$ as the starting-point of movement or endeavor, part of the thing from which its genesis begins (such as the foundation of a house), the external starting-point of genesis or movement (efficient cause, including natural causation such as a child from its father and mother), that which moves something else at its will (such as city powers and dignitaries as well as creative causation in producing art), and that from which knowledge of a thing starts (such as epistemological premises of proofs). ${ }^{37}$

John of Damascus distinguished between $\alpha p x \dot{\eta}$ in terms of time, place, dignity and power, preceding sequence of numbers, order, and causality which was triple and included a natural cause, creative cause, and imitative cause. ${ }^{38}$ John of Damascus argued that in neither of these kinds one could find two unoriginate yet opposing $\dot{\alpha} p \chi \alpha i$. In terms of time, any changing principle, either from the bodiless state into a body, or from the invisible state into some form, or from quietude to turmoil (which were the stages of the Manichaean myth) would become something new which it had not been before and thus could not be unoriginate. ${ }^{39} \mathrm{In}$ terms of space, the opposites could not be located within each other because this would lead to their mutual destruction, but each one had to occupy its own limited space separated by a boundary to avoid interpenetration. Thus there would be light and its space, darkness and its space, and the boundary, which would altogether give five primordial principles instead of two. ${ }^{40}$ Both power and dignity were relational, implying power and dignity over something, which in the case of the two principles would mean either that one would rule over the other, or that both would not rule over anything, or there would be some other subordinate principle over which two principles would exercise their power, which would multiply the number of the primordial principles if they were coeternal with the two, or annihilate the power of the two if the subordinate principles were not co-

${ }^{36}$ Dialogus contra Manichaeos, 18-19, ed. Kotter 1981, 362.1-6. Cf. Aristotle, Topics I, 12, 105 .

${ }^{37}$ Metaphysics V, 1, 1013a; Ross 1975, 290.

${ }^{38}$ Dialogus contra Manichaeos, 3 , ed. Kotter 1981, 353.3-17. On the notion of $\alpha p x \eta \dot{~ i n ~ t h e ~}$ Fathers associated with the Genesis account of creation, see van Winden 1997. On Basil's and Ambrose's treatment of $\alpha$ pxí, see van Winden 1963.

${ }^{39}$ Dialogus contra Manichaeos, 5; ed. Kotter, 1981, 354.2-7.

${ }^{40}$ Dialogus contra Manichaeos, 7; ed. Kotter, 1981, 355.1-10. 
eternal and there was a state when they did not yet exist. ${ }^{41}$ Two principles could also not be conceived from the viewpoint of natural causality: if they were the originators of beings as natural causes, everything would be coeternal and consubstantial to these principles, and therefore unchangeable. ${ }^{42}$ If the two principles were considered from the viewpoint of creative causality, both souls and bodies would not emanate from these principles but would come into being from non-being, and matter would not fight with light and would not capture its particle to produce souls. Moreover, John argued that it was inconceivable that two opposite principles could come together in agreement for creating a single world and single man.

In addition to Aristotelian works, another important genre of literature which was likely used in the Dialogue by John of Damascus was anti-Manichaean writings composed not for strictly polemical purposes, but for instructional purposes of Neoplatonic education, logically evolving from the inner Platonist strain between the monist and dualist principles imbedded into Plato's cosmogony and cosmology. ${ }^{43}$

Although Plato described the Receptacle in Timaeus $30 \mathrm{~A}$ and ${ }_{52 \mathrm{E}}-53 \mathrm{~A}$ as a source of disorderly motion, it was only used as a notion for explaining diversity in the world, some of which might result in the options which we might perceive as evil. In Plato's successor Speusippus, two primary principles were the One possessing utmost simplicity and Multiplicity facilitating division and associated with fluid matter. These principles were not in opposition to each other; Multiplicity simply assisted the One in fostering diversity and individuation of the cosmos. Xenocrates placed the sublunar region under the rule of a "lower Zeus" who can be identified with Hades and may be in some way associated with the deity mentioned by Plutarch as Pluto/Hades who also ruled the sublunar realm, regulated changeableness in the world, and was contrasted, although not strictly opposed to, with a transcendent deity identified with Apollo. Antiochus of Ascalon in the first century B.C. proposed an active principle and passive principle of matter as formless substance devoid of any quality. Eudorus of Alexandria also followed the monist line of thought proposing a supreme One above the pair of Monad and Indefinite Dyad, warranting all existence including matter.

However, in the late first century A.D. another, dualist tendency started to prevail in Platonist discussions. Thus, in addition to a subordinate, sublunar deity, Plutarch introduced a much more radically evil power in the universe, whose

\footnotetext{
${ }^{41}$ Dialogus contra Manichaeos, 9; ed. Kotter, 1981, 356.1-7.

${ }^{42}$ Dialogus contra Manichaeos, 10; ed. Kotter, 1981, 356.1-13.

${ }^{43}$ In the following I am summarizing an overview of Dillon 2008.
} 
strife represented the tension of opposites, preserving the world's existence. The Indefinite Dyad acted as the evil principle; Unlimitedness was the principle of formlessness and disorder, yet the One limited and contained the void, irrational, and indeterminate in Unlimitedness. In the second century A.D., Numenius of Apamea propagated a dualistic system, equating Matter with the Indefinite Dyad and Maleficent Soul of Plutarch, and considering Matter to be fluid and devoid of quality, yet clearly evil. Plotinus inherited this distinctly dualist tendency of Platonism in his discussion of matter and evil, ${ }^{44}$ at the time when Manichaeism started to enter the Roman Empire.

For the later Neoplatonism, Manichaeism became a "punching bag" both in the process of articulating the "normative" Platonic teaching ${ }^{45}$ and in instructing students in logic by exposing the logical flaws in the basic Manichaean doctrines or Manichaean paralogisms, after incorporating Aristotelian logical treatises and his methodology of syllogistic proofs into the curriculum. ${ }^{46}$ The course of studying the works of Aristotle, before studying Plato's dialogues, acquired a standardized and organized shape in the mid fifth century by the time of Proclus, who thus justified the use of studying paralogisms in the prologue to his commentary on Euclid's Elements, which was also a part of the curriculum: "Since there are many matters that seem to be dependent on truth and to follow from scientific principles but really lead away from them and deceive the more superficial students, he [Euclid] has given us methods for clear-sighted detection of such errors; and if we are in possession of these methods, we can train beginners in this science for the discovery of paralogisms and also protect ourselves from being led astray. ${ }^{m 7}$ Manichaean arguments became particularly actively discussed in the sixth century by such thinkers as Simplicius, John Philoponus, Zacharias Scholasticus, Severus of Antioch, John the Grammarian, and Paul the Persian, some of whom studied philosophy in Alexandria from Ammonius, the Neoplatonist philosopher and student of Proclus, and who later taught and practiced grammar, rhetoric, and philosophy. ${ }^{48}$

${ }^{44}$ See Rist 1961; O’Brien 1981. For the debate with D. O'Brien, see Phillips 2009.

${ }^{45}$ For Simplicius, see Lieu, Sheldon 2011.

${ }^{46}$ On the early stages of this process in Clement of Alexandria, Alcinous, Atticus, and Proclus, see Bechtle 2013. On Neoplatonic curriculum, see Bennett 2015, 23-27; Bennett 2021. See also Lloyd 1955; Lloyd 1956, and O'Meara 2009. On typical mistakes of logical argumentation according to Aristotle, see Schreiber 2003.

${ }^{47}$ Proclus, In primum Euclidis elementorum librum commentarii 70.1-9; Morrow 1970, 58 , cited in Bennett 2021, 427 .

${ }^{48}$ Bennett 2015, 19. 
A good example of the intersecting traditions of the Late Antique Neoplatonic and Christian education, and borrowing of the Neoplatonic curriculum by the Christians is the early sixth century First Homily against the Manichaeans by John the Grammarian, which in fact is not a homily but lecture notes by a Christian teacher of Neoplatonic philosophy on several problems related to matter and light resulting from the Manichaean worldview, and their solutions using Neoplatonic philosophical methods. ${ }^{49}$ The structure of the Homily strongly resembles the part of the Dialogue by John of Damascus which refuted the propositions of the Manichaean cosmology. Both treatises start with a brief epistemological introduction, present the problem in the form of a proposition (matter is living and ungenerated) in John the Grammarian and the Manichaean cosmogonic myth in John of Damascus, and go on to refute it by syllogistic argumentation based on Aristotelian premises.

Because of largely common methods of advanced education among pagans and Christians, the same arguments, albeit sometimes appearing in differing wording and supplied by different examples, resurface in a number of various treatises, both pagan and Christian. Thus, the argument on the commonality of contraries in substance appears in John of Damascus, John the Grammarian's treatise, in a collection of syllogisms attributed to Didymus the Blind (reproducing a passage from John the Grammarian as a separate syllogism), and Simplicius, and are all based on Aristotle's discussions of contrariety.

Thus, two Byzantine philosophical works of the sixth century: Zacharias of Mitylene's Adversus Manichaeos and Defensio ('A $\pi 0 \lambda \circ \gamma$ 'i $\alpha$ ) attributed to Paul the Persian refute a brief anonymous treatise on two unoriginate principles entitled The Proposition of a Manichaean which most likely survived from a Neoplatonist milieu where it was used as a teaching aid for students of logic. The main polemical method was exposing its logical flaws, primarily, a mistake in category by opposing not contraries, but relatives. ${ }^{50}$

John of Damascus used a similar argument on contraries existing only in substance which therefore is their common and more primary entity, in his ontological criticism of the Manichaean concept of light and darkness as two unoriginate principles. The boundary separating the two in each realm must be considered as its own unoriginate, third principle.

Thus, the two [principles] either would be in each other or would be circumscribed by place and not be unoriginate. How then can light and darkness be in each other?

\footnotetext{
${ }^{49}$ Bennett 2015 .

${ }^{5}$ Bennett 2021, 419-421.
} 
For light destroys darkness. If there is no boundary of light and boundary of darkness, neither light would be incircumscribable since it is not everywhere, nor darkness (Ei

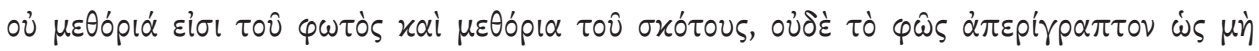

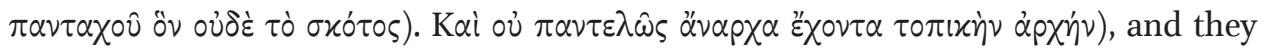
are not completely unoriginate having a spatial principle. For it is impossible for light and darkness to be entirely unmixed without some barrier or partition. ${ }^{51}$

At first sight, this explanation is puzzling, since circumscription is precisely the capacity to be limited by a certain outline or border, and without the boundary light should be called incircumscribable. None of the manuscripts used for the critical edition indicate a variant reading suggesting a scribal error so we have to assume this is the original formulation. We can solve this puzzle by viewing the example which John of Damascus provides as an illustration to his argument:

If we lit a lamp at night, the space around the lamp would be lighter, and it would be darker at a small distance until the light completely disappears and there is pure darkness without admixture of light. So either from the beginning darkness was mixed with light and these are not completely opposite and uncommunicating, or something else was the boundary dividing those from the beginning, and thus there are not two principles but three..$^{2}$

These examples are taken from the physical world where unrestrained light does not spread infinitely but fades away with distance and is viewed as an empirical phenomenon paired with darkness as another empirical phenomenon. It is likely that while speaking about light and darkness, as a background text, John of Damascus and his readers had in mind the verse from the Prologue to the Gospel of John "The light shines in the darkness, and the darkness has not overcome

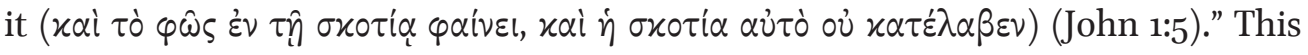
divine light of the Word is the only incircumscribable light penetrating the whole of creation and beyond, while in the physical world, light is always coupled with darkness as the shadow cast by an object lit by the sun. Physical light and darkness are interrelated natural phenomena - the more light, the less darkness and vice versa; they manifest themselves in space as in a common underlying substance. In addition, given the natural paradigm of John's explanation, not only space might have been the commonality where light and darkness exist but also

\footnotetext{
${ }^{51}$ Dialogus contra Manichaeos, 22, ed. Kotter 1981, 363.1-7.

${ }^{52}$ Ibid., 363.8-10. Cf. Dialogus contra Manichaeos, 7, ed. Kotter 1981, 355.2-7, and Severus of Antioch, Homily 123, Brière 196o, 151.17-153.7.
} 
air, since two theories of vision in Late Antiquity - Aristotelian and Galenic - required the presence of air as a mediating substance..$^{53}$

Moreover, the example also shows that similar to earlier polemicists, John of Damascus does not present light and darkness as absolute contraries, since they involve an infinite number of intermediate states of "lighter" or "darker." John of Damascus describes this kind of contraries in Chapter 57, "On Opposites," in his Dialectica:

Some contraries have no intermediate, whereas others have.....Now, those which have an intermediate are those of which one or the other must not necessarily be in the subject, or in the things of which they are predicated. An example is that of white and black, for these are contraries, yet it is not at all necessary for one of them to be in the body, because it is not necessary for every body to be either white or black-there are gray bodies and tawny ones. ...in the case of those contraries which have intermediates, some of the intermediates have names, as the mean between white and black is called gray. ${ }^{54}$

In the same chapter John of Damascus also mentions that contraries are not primary principles since they "come under the same genus, as white and black under color. ${ }^{55}$

In an earlier article on the Dialogue, the conclusion was set forth that the problem of divine providence was not the main scope of the Dialogue for John of Damascus, but was a corollary of his Christian ontological attempt to ascribe all causality to a single divine and benevolent principle..$^{56}$ This research makes it possible to adjust the previous conclusion. The ease in refuting the key points of the Manichaean myth by employing various arguments based on Aristotelian methods of proof, as well as likely adoption of ready-made syllogisms from the school tradition of instruction in logic stand out against the "real voice" of John of Damascus in the second part of the treatise, where he focuses on the matters of divine providence and foreknowledge which would correct voluntary abuses of human free will, and masterfully rethinks the solutions to the problems of theod-

\footnotetext{
${ }^{53}$ See Lorenz 2007; Ierodiakonou 2014; Betancourt 2018; Ierodiakonou 2020 (with bibliography).

${ }^{54}$ Dialectica, 57; ed. Kotter 1969, 125.15-126.27, transl. Chase 1958, 88-89.

${ }^{55}$ Dialectica, 57; ed. Kotter 1969, 126.43-44, transl. Chase 1958, 9o. Cf. Simplicius: "For this reason it is impossible for opposites to be prime causes: their classification must have existed prior to them" (transl. Lieu, Sheldon 2011, 219), based on Aristotle, Categories 8, 10b17-18.

${ }^{5}$ Baranov 2019, 10.
} 
icy proposed by Basil of Caesarea. This may indicate that the latter issues were targeted in the Dialogue, which can be regarded as a curious practical application of the Aristotelian philosophical tradition of Late Antiquity appearing in the Dialectica.

It does not really matter whether John of Damascus acquired his knowledge of Manichaeism from direct encounter, written testimony on the Manichaean doctrines, or in a course of theological training (or through any combination of these), since it is unlikely that Manichaeism was a real threat to his audience and the primary target of his polemics. It is quite possible that clear Manichean theodicy relegating all very real evils empirically present in the world to an independent principle, which must have been a pressing issue in the times of social and political instability, could have been appealing to some Christians. John of Damascus might have had a multiple purpose in mind while composing his Dialogue, first discrediting the Manichaean doctrines, including Manichaean cosmogony, cosmology, and theodicy based on the developed tradition of antiManichaean polemics, and then offering a correct alternative in the form of divine, benevolent foreknowing activity, combined with human free will, which acts not on human free actions but on their consequences. The overall logic of the Dialogue may be viewed in reverse order: everyone who does not believe in the providence of a good God over creation but believes in some independent existence of evil outside of the free choice of rational beings inevitably joins the ranks of the Manichees, whose cosmological myth is based on logical flaws and does not stand elementary rational scrutiny. However, the Dialogue should also be viewed from a wider perspective as a nexus of intersecting themes, including the philosophical thought of the last generation of Greek-speaking thinkers in Palestine. The Dialogue is not only a polemical treatise but a witness to the end of the Late Antique educational curriculum, ${ }^{57}$ and the culture of public disputations of Late Antiquity, receiving new life in the Islamic environment. ${ }^{8}$

\footnotetext{
${ }^{57}$ Following the suggestion that anti-Manichaean polemics in Late Antiquity was a part of standard rhetorical training for the theologians, A. Louth proposed an early date of the Dialogue which John could compose still in Damascus in the course of such training (Louth 2002, 71 based on Lieu 1988, 175). The philological analysis of the parallels between the Dialogue and Dialectica at different stages of its development might clarify this issue.

${ }^{58}$ See Lim 1992; Lim 1995; Szilágyi 20o9; Bertaina 2011 (see the critical review of this work in Szilágyi 2015); Griffith 1992; Griffith 2000.
} 


\section{REFERENCES}

Ables, S. (2019) "The Purpose of the Anti-Manichaean Polemic of John of Damascus," Paper read at the August 2019 Oxford Patristics Conference in the "More than a Compiler: Workshop on John of Damascus." https://www.academia.edu/41035013/The_Purpose_of_the_Anti_Manichaean_Polemic_of_John_of_Damascus. Accessed January 12, 2021.

Awad, N. G. (2018) Umayyad Christianity. John of Damascus as a Contextual Example of Identity Formation in Early Islam, Islamic History and Thought 12, Piscataway, NJ: Gorgias Press.

Baran Tekin, D. (2017) "Mani and His Teachings according to Islamic Sources: An Introductory Study," in: Lieu, S. N. C., Pedersen, N. A., Morano, E., Hunter, E., eds. Manichaeism East and West, Corpus Fontium Manichaeorum. Analecta Manichaica 1, Turnhout: Brepols, 1-9.

Baranov, V. A. (2019) "Human Destiny and Divine Providence in Two Byzantine Authors of the Early Eighth Century," Scrinium. Journal of Patrology and Critical Hagiography 15, 3-29.

Bechtle, G. (2013) 'Harmonizing' Aristotle's Categories and Plato'a Parmenides before the Background of Natural Philosophy," in: Corrigan, K., Rasimus, T., eds., Gnosticism, Platonism, and the Late Ancient World: Essays in Honour of John B. Turner, Nag Hammadi and Manichaean Studies 82, Leiden: Brill, 543-568.

Bennett, B. (1997) The Origin of Evil. Didymus the Blind's Contra Manichaeos and Its Debt to Origen's Theology and Exegesis, Ph.D. Dissertation, Toronto.

Bennett, B. (2001) "Iuxta unum latus erat terra tenebrarum: The Division of Primordial Space in Anti-Manichaean Writers' Descriptions of the Manichaean Cosmogony," in: Mirecki, P., BeDuhn, J., eds., The Light and the Darkness: Studies in Manichaeism and its World, Nag Hammadi and Manichaean Studies 5o, Leiden: Brill, 68-78.

Bennett, B. (2009) "The Conversation of John the Orthodox with a Manichaean: An Analysis of its Sources and Its Significance for Manichaean Studies," in: BeDuhn, J. D., ed., New Light on Manichaeism: Papers from the Sixth International Congress on Manichaeism, Nag Hammadi and Manichaean Studies 64, Leiden: Brill, 29-44.

Bennett, B. (2015) “The Physics of Light, Darkness and Matter in John the Grammarian's First Homily against the Manichaeans: Early Byzantine Anti-Manichaean Literature as a Window on Controversies in Later Neoplatonism," in: Richter, S. G., Horton. C., Ohlhafer, K., eds. Mani in Dublin. Selected Papers from the Seventh International Conference of the International Association of Manichaean Studies in the Chester Beatty Library, Dublin, 8-12 September 2009, Nag Hammadi and Manichaean Studies 88, Leiden: Brill, 19-33.

Bennett, B. (2021) "The Afterlife of Manichaeism in Neoplatonic Education," in: Manichaeism and Early Christianity. Selected Papers from the 2019 Pretoria Congress and Consultation. van Oort, J., ed., Nag Hammadi and Manichaean Studies 99) Leiden: Brill, 401-431.

Bermejo, F. (2015) "Primal Man, Son of God: From Explicit to Implicit Christian Elements in Manichaeism," in: Richter, S. G., Horton, C., Ohlhafer, K., eds. Mani in Dublin. Selected Papers from the Seventh International Conference of the International Association of 
Manichaean Studies in the Chester Beatty Library, Dublin, 8-12 September 2009, Nag Hammadi and Manichaean Studies 88, Leiden: Brill, 34-46.

Bertaina, D. (2011) Christian and Muslim Dialogues: The Religious Uses of a Literary Form in the Early Islamic Middle East, Gorgias Eastern Christian Studies 29, Piscataway, NJ: Gorgias Press.

Betancourt, R. (2018) Sight, Touch, and Imagination in Byzantium, Cambridge: Cambridge University Press.

Brière, M., ed. and transl. (1960) Les Homiliae cathedrales de Sévère d'Antioche: Homélies CXX à $C X X V$. Patrologia Orientalis 138 (29.1), Paris: Firmin-Didot.

Brinkmann, A., ed. (1895) Alexandri Lycopolitani Contra Manichaei opiniones disputatio. Leipzig: B. G. Teubner.

Chase, F. H., Jr., transl. (1958) Saint John of Damascus. Writings, Fathers of the Church Patristic Series 37, Washington, D. C.: The Catholic University of America Press.

Coyle, J. K. (20oga) "Good Tree, Bad Tree: The Matthean/Lukan Paradigm in Manichaeism and Its Opponents," in: Idem., Manichaeism and Its Legacy, Nag Hammadi and Manichaean Studies 69, Leiden: Brill, 65-88.

Coyle, J. K. (20ogb) "The Idea of the 'Good' in Manichaeism," in: Idem., Manichaeism and Its Legacy (Nag Hammadi and Manichaean Studies 69), Leiden: Brill, 51-64.

Dick, I., ed. (1982) Théodore Abuqurra: Traité de l'existence du Créateur et de la vraie religion, Patrimoine arabe chrétien 3, Rome: Pontificio Istituto Oriental.

Dillon, J. (2008) "Monist and Dualist Tendencies in Platonism before Plotinus," $\Sigma X O \Lambda H$ (Schole) 1, 37-50.

Erismann, C. (2010) “A World of Hypostases: John of Damascus's. Rethinking of Aristotle's Categorical Ontology," Studia Patristica 50, 251-269.

Erismann, C. (2017) "Logic in Byzantium," in: Kaldellis, A., Sinissoglou, N., eds., The Cambridge Intellectual History of Byzantium, Cambridge: Cambridge University Press, 362-380.

Esmailpour A. (2005) Manichaean Gnosis and Creation Myth, Sino-Platonic Papers 156, Philadelphia, PA: Department of East Asian Languages and Civilizations, University of Pennsylvania.

Fox, G., Sheldon, J., and Lieu, S. N. C. (2010) Greek and Latin Sources on Manichaean Cosmogony and Ethics, Corpus Fontium Manichaeorum, Series Subsidia 6, Turnhout: Brepols.

Gardner, I. and S. N. C. Lieu, eds. (2004) Manichaean Texts from the Roman Empire, Cambridge: Cambridge University Press.

Giet, S., ed. transl., and intro. (1950) Basile de Césarée, Homélies sur l'Hexaéméron, Sources chrétiennes 26, Paris: Editions du Cerf.

Griffith, S. (1987) "Free Will in Christian Kalām: The Doctrine of Theodore Abū Qurrah," Parole de l'Orient 14, 79-107.

Griffith, S. (1992) "Disputes with Muslims in Syriac Christian Texts: From Patriarch John (d. 648 ) to Bar Hebraeus (d. 1286)," in: Lewis B., Niewöhner, F., eds, Religionsgespräche im Mittelalter, Wolfenbütteler Mittelalter-Studien 4, Wiesbaden: Otto Harrassowitz, 251273.

Griffith, S. (2000) "Disputing with Islam in Syriac: the Case of the Monk of Bêt Halê and a Muslim Emir,” Hugoye: Journal of Syriac Studies 3.1, 29-54. 
Griffith, S. (2006) "The Church of Jerusalem and the 'Melkites': The Making of an 'Arab Orthodox' Christian Identity in the World of Islam (750-1050 ce)," in: Limor, O., Stroumsa, G. G., eds. Christians and Christianity in the Holy Land, Cultural Encounters in Late Antiquity and the Middle Ages 5, Turnhout: Brepols, 175-204.

Griffith, S. (2011) "John of Damascus and the Church in Syria in the Umayyad Era: The Intellectual and Cultural Milieu of Orthodox Christians in the World of Islam," Hugoye: Journal of Syriac Studies 11.2, 207-238.

Griffith, S. (2016) "The Manșūr Family and Saint John of Damascus: Christians and Muslims in Umayyad Times," in: Borrut A., Donner F. M., eds. Christians and Others in the Umayyad State, Late Antique and Medieval Islamic Near East 1, Chicago, Il.: The University of Chicago, 29-51.

Ierodiakonou, K (2014) "Galen's Theory of Vision," in: Adamson, P., Hansberger, R. Wildberding, J., eds. Philosophical Themes in Galen, Bulletin of the Institute of Classical Studies, Supplement 114, London: Institute of Classical Studies, School of Advanced Study, University of London, 235-247.

Ierodiakonou, K. (2020) "Byzantine Theories of Vision," in: Lazaris S., ed. A Companion to Byzantine Science, Brill's Companions to the Byzantine World 6, Leiden: Brill, 160-176.

Ierodiakonou, K. and D. O'Meara (2008) "The Study of Byzantine Philosophy," in: Jeffreys, E., Haldon, J., Cormack, R., eds., The Oxford Handbook of Byzantine Studies. Oxford: Oxford University Press, 711-720.

Khosroev, A. L. (2007) Istoriya manikheistva (Prolegomena). Istochniki i issledovaniya [The history of Manichaeism (Prolegomena). Sources and research], Saint Petersburg: Filologicheskij fakul'tet Sankt-Peterburgskogo universiteta.

Klein, W. W. (1991) Die Argumentation in den griechisech christlichen Antimanichaica, Studies in Oriental Religions 19, Wiesbaden: Otto Harrassowitz.

Kotter, B., ed. (1969) Johannes Damascenus. Institution elementaris. Capita philosophica (Dialectica), Die Schriften des Johannes von Damaskos I, Patristische Texte und Studien 7 , Berlin: De Gruyter.

Kotter, B. ed. (1981) Johannes von Damaskos. Liber de haeresibus. Opera polemica, Die Schriften des Johannes von Damaskos IV, Patristische Texte und Studien 22, Berlin, New York: De Gruyter.

Lieu, S. N. C. (1985-1986) "Some Themes in Later Roman Anti-Manichaean Polemics I," Bulletin of the John Rylands Library 68.2, 434-472.

Lieu, S. N. C. (1986-1987) "Some Themes in Later Roman Anti-Manichaean Polemics II," Bulletin of the John Rylands Library 69, 235-275.

Lieu, S. N. C. (1988) Manichaeism in the Later Roman Empire and Medieval China: A Historical Survey. Manchester: Manchester University Press.

Lieu, S. N. C. (1992) Manichaeism in the Later Roman Empire and Medieval China, 2d ed., Wissenschaftliche Untersuchungen zum Neuen Testament 63, Tübingen: Mohr Siebeck.

Lieu, S. N. C., Sheldon, J. (2011) "Simplicius on Manichaean Cosmogony," in: van den Berg, J. A. et al., eds. "In Search of Truth": Augustine, Manichaeism and Other Gnosticism, Studies for Johannes van Oort at Sixty, Nag Hammadi and Manichaean Studies 74, Leiden: Brill, 217-228. 
Lim, R. (1992) "Manichaeans and Public Disputation in Late Antiquity," Recherches Augustiniennes et Patristiques 26, 233-272.

Lim, R. (1995) Public Disputation, Power, and Social Order in Late Antiquity, Berkeley, Los Angeles, and Oxford: University of California Press.

Lloyd, A. C. (1955) “Neoplatonic Logic and Aristotelian Logic: I," Phronesis 1.1, 58-72.

Lloyd, A. C. (1956) "Neo-Platonic Logic and Aristotelian Logic: II," Phronesis 1.2, 146-16o.

Lorenz, H. (2007) "The Assimilation of Sense to Sense-Object in Aristotle," Oxford Studies in Ancient Philosophy 33, 179-220.

Louth, A. (2002) St. John Damascene: Tradition and Originality in Byzantine Theology, Oxford Early Christian Studies, Oxford: Oxford University Press.

Migne J.-P., ed. (1857-1866) Patrologia Graeca, Paris (PG).

Morrow, G. R. (1970) Proclus. A Commentary on the First Book of Euclid's Elements, Princeton, NJ: Princeton University Press.

O’Brien, D. (1981) "Plotinus and the Gnostics on the Generation of Matter," in: Blumenthal, H. J., Markus, R. A., eds., Neoplatonism and Early Christian Thought, Essays in Honour of A. H. Armstrong, London: Variorum, 108-123.

O’Meara, D. (2009) "Transformatsiya metaphiziki v epokhu pozdnei antichnosti” [The Transformation of Metaphysics in Late Antiquity]. $\Sigma X O \Lambda H$ (Schole) 3.2, 416-432.

Pedersen, A. (1989) "Between Essence and Existence, A Paradox of the Manichaean System in the Coptic Texts," Rivista degli studi orientali 63, 1/3, 45-64.

Pedersen, N. A. (2004) Demonstrative Proof in Defence of God-A Study of Titus of Bostra's Contra Manichaeos: The Work's Sources, Aims and Relation to its Contemporary Theology, Nag Hammadi and Manichaean Studies 56, Leiden: Brill.

Phillips, J. (2009) "Plotinus on the Generation of Matter," The International Journal of the Platonic Tradition 3, 103-137.

Puech, H.-C. (1979) "Le prince des tenebres et son royaume," in Idem, Sur le manichéisme et autres essais, Paris: Flammarion, 103-151.

Reeves, J. C. Prolegomena to a History of Islamicate Manichaeism, Comparative Islamic Studies. Sheffield, Oakville, CT: Equinox Publishing.

Richter, G. (1964) Die Dialektik des Johannes von Damaskus: Eine Untersuch. Des Textes nach seinen Quellen und seiner Bedeutung, Studia Patristica et Byzantina 10, Ettal: BuchKunstverlag.

Rist, J. M. (1961) "Plotinus on Matter and Evil," Phronesis 6.2, 154-166.

Roman, A., Schmidt, T. S., Pourier, P.-H., Crégheur, É., Declerck, J. H., eds. (2013) Titi Bostrensis Contra Manichaeos Libri IV: Graece et Syriace, Corpus Christianorum, Series Graeca 82, Turnhout: Brepols.

Ross, W. D. (1975) Aristotle's Metaphysics. A Revised Text with Introduction and Commentary, vol. 1. Oxford: Clarendon Press.

Roueché, M. (1974) "Byzantine Philosophical Texts of the Seventh Century," Jahrbuch der Österreichischen Byzantinistik 23, 61-76.

Roueché, M. (1980) “A Middle Byzantine Handbook of Logic Terminology," Jahrbuch der Österreichischen Byzantinistik 29, 71-98. 
Schadler, P. John of Damascus and Islam. Christian Heresiology and the Intellectual Background to Earliest Christian-Muslim Relations, History of Christian-Muslim Relations 34, Leiden, Brill.

Schreiber, S. G. (2003). Aristotle on False Reasoning. Language and the World in the Sophistical Refutations, SUNY series in Ancient Greek Philosophy. Albany, NY: State University of New York Press.

Smagina, E. (2011) "The Manichaean Cosmogonical Myth as a 'Re-written Bible'," in: van den Berg J. A. et al., eds. "In Search of Truth": Augustine, Manichaeism and Other Gnosticism, Studies for Johannes van Oort at Sixty, Nag Hammadi and Manichaean Studies 74, Leiden: Brill, 201-216.

Stroumsa, S., Stroumsa, G. (1988) "Aspects of Anti-Manichaean Polemics in Late Antiquity and Under Early Islam," Harvard Theological Review 81.1, 37-58.

Szilágyi, K. (2009) "A Prophet Like Jesus? Christians and Muslims Debating Muhammad's Death," Jerusalem Studies in Arabic and Islam 36, 131-171.

Szilágyi K. (2015) "Review of Bertaina, D. Christian and Muslim Dialogues: The Religious Uses of a Literary Form in the Early Islamic Middle East, Gorgias Eastern Christian Studies 29, Piscataway, NJ: Gorgias Press, 2011," Hugoye:Journal of Syriac Studies 18.1, 287-306.

Tannous, J. B. V. (2010) Syria between Byzantium and Islam: Making Incommensurables Speak, vol. 1, Ph.D. Dissertation, Princeton University.

Tardieu, M. (2008) Manichaeism, DeBevoise, M. B., transl., Urbana and Chicago, IL: University of Illinois Press.

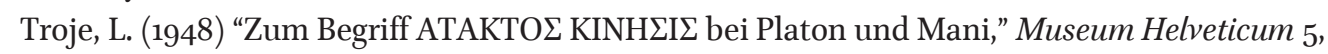
96-115.

van der Horst, P. W., Mansfeld, J., transl. with intro. and notes (1974) An Alexandrian Platonist against Dualism: Alexander of Lycopolis' Treatise “Critique of the Doctrines of Manichaeus." Leiden: Brill.

van Oort, J. (2013) "Alexander of Lycopolis, Manichaeism and Neoplatonism," in: Corrigan, K., Rasimus, T., eds., Gnosticism, Platonism, and the Late Ancient World: Essays in Honour ofJohn B. Turner, Nag Hammadi and Manichaean Studies 82, Leiden: Brill, 275-283.

Van Roey, A. (1944) "La Lettre apologétique d'Élie à Léon, syncelle de l'évêque chalcédonien de Harran," Le Muséon 57, 1-52.

van Winden, J. C. M. (1963) "In the Beginning: Some Observations on the Patristic Interpretations of Genesis 1, 1," Vigiliae Christianae 17, 105-121.

van Winden, J. C. M. (1997) "In the Beginning: Early Christian Exegesis of the Term Arche in Genesis 1:1, Inaugural Address, Leiden 1967 (translated from the Dutch)," in: den Boeft, J., Runia, D. T., eds., Arche: A Collection of Patristic Studies, Vigiliae Christianae, Supplements 41, Leiden: Brill, 78-93. 